\title{
Mechanical performance of eco-efficient hollow clay bricks incorporating industrial nano-crystalline aluminium sludge
}

\author{
Eduardo Cavaco $^{a^{*}}$, Inês Grilo ${ }^{\text {, João Paulo Gouveia }}{ }^{\mathrm{c}}$, Eduardo Júlio $^{\mathrm{d}}$, Luís Neves ${ }^{\mathrm{e}}$
}

\begin{abstract}
In this paper, mechanical properties of a new structural and eco-efficient hollow clay bricks are investigated. The principal goal was to recycle residual sludge from aluminium anodizing industries by incorporating it in the raw material of bricks, thus contributing for the sustainability of the construction sector. It was also an objective to enhance thermal properties of the bricks, contributing to improve the energy efficiency of buildings, and maintain their mechanical properties.

A large set of mechanical tests was conducted. A comparison between traditional, structural, and the new eco-efficient bricks is established. Results show that the mechanical properties of the new bricks and masonry are not significantly affected by the aluminium sludge, thus allowing their use without strength limitations, and taking advantage from the thermal improved performance.
\end{abstract}

Keywords: clay brick; aluminum sludge; structural and eco-efficient brick; masonry.

\footnotetext{
${ }^{a}$ CERIS, DEC, Faculdade de Ciências e Tecnologia, Universidade NOVA de Lisboa, Almada, Portugal ${ }^{\mathrm{b}}$ DEC, Instituto Superior de Engenharia de Coimbra, Instituto Politécnico de Coimbra, Coimbra, Portugal ${ }^{\mathrm{c}}$ DEC, Instituto Superior de Engenharia de Coimbra, Instituto Politécnico de Coimbra, Coimbra, Portugal

${ }^{\mathrm{d}}$ CERIS, DECivil, Instituto Superior Técnico, Universidade de Lisboa, Lisboa, Portugal

${ }^{\mathrm{e}}$ Centre for Risk and Reliability Engineering, University of Nottingham

*e.cavaco@fct.unl.pt (*Corresponding author)
} 


\section{INTRODUCTION}

Clay bricks are one of the most ancient and building materials worldwide widely used, mainly due to their low cost, and thermal, acoustic and structural advantages. Among other applications, clay bricks have been used in partition nonstructural masonry walls, façades and in structural masonry. Their properties have improved through times thus enhancing the performance of masonry walls. As a result, nowadays many different types of clay bricks, varying predominantly in geometry and in raw material composition, can be found in the construction market.

Having reached high compressive strengths, hollow clay bricks started to also be used in structural walls. Thus, currently the goal is to have clay bricks presenting a mechanical performance adequate for structural applications and simultaneously an optimal thermal performance, due to an increasing demand to improve the energy efficiency of buildings (Santos, Martins, \& Júlio, 2015; Neto, 2010; Pérez-Lombard, Ortiz, \& Pout, 2008; Raut, Ralegaonkar, \& Mandavgane, 2013; Tiago \& Júlio, 2010). With this aim, clay bricks manufacturers have been working intensely on improving the brick geometry (Drysdale, Hamid, Baker, \& others, 1994; Hendry, 2001). While, traditional hollowed bricks tend to present horizontal holes, since the last decade and in accordance with the classification defined by Eurocode 6 (ECS, 2003), vertical hollowed bricks have been developed presenting much better thermal and acoustic insulation, and higher mechanical strength.

Sustainability concerns are an up-to-date subject to all industries, the ceramic industry included, being the latter particularly relevant due to the large quantity of bricks produced worldwide. In this context, besides the aim already mentioned above, the enhancement of energy efficiency of buildings, the goal is to implement eco-friendly measures such as incorporating recycled materials and industrial by-products in the raw material of clay bricks (Neto, 2010). However, besides the environmental and thermal benefit, a poor mechanical strength is usually found, therefore limiting the use of this type of clay bricks in structural masonry walls.

This paper presents the mechanical characterization of eco-efficient perforated clay bricks obtained through the incorporation of industrial nano-crystalline aluminium sludge in the raw material. The main motivation of the work herein described was to solve an environmental problem, the landfill disposal of residual sludge from aluminium anodizing and lacquering industries, by incorporating it in the raw material of clay bricks, this way contributing for the sustainability of the construction sector. However, it has also been defined that the thermal properties of the original clay bricks should be enhanced, this way contributing to improve the energy efficiency of buildings, and that the mechanical properties should not be significantly reduced. 
The clay bricks used in this research study were produced at Preceram, the leading ceramic industry in Portugal. Mechanical properties of traditional clay bricks, with horizontal hollows, and thermal clay bricks, with vertical hollows, the latter produced with and without incorporating the industrial nano-crystalline aluminium sludge, as well as masonry specimens produced with all types considered, were tested and compared. The durability characterization of the new product is not in the scope of the present paper but will be specifically addressed in future research. For the sake of clarity, from this point onwards, traditional clay bricks with horizontal hollows will be referred to as traditional bricks (TB), Figure 1 (a), and thermal bricks with vertical hollows, Figure 1 (b), will be referred to as either original thermal bricks $(\mathrm{OB})$ or ecological thermal bricks $(\mathrm{EB})$, respectively if produced with the original raw material or incorporating the industrial nano-crystalline aluminium sludge. Both TB and OB have been used mostly for façade and partition walls. Although, with non-negligible mechanical properties, in particular in the latter case, their contribution for structural purposes have been usually neglected by designers.

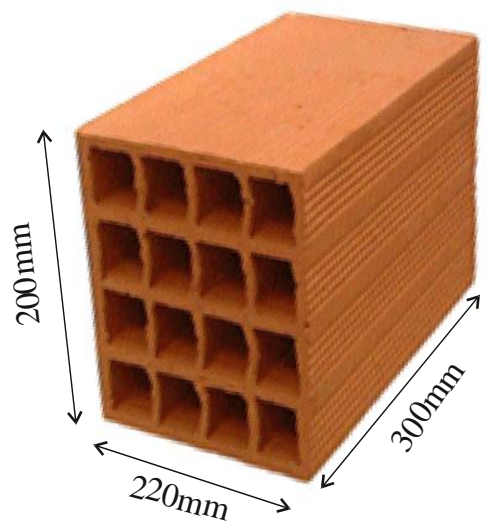

(a)

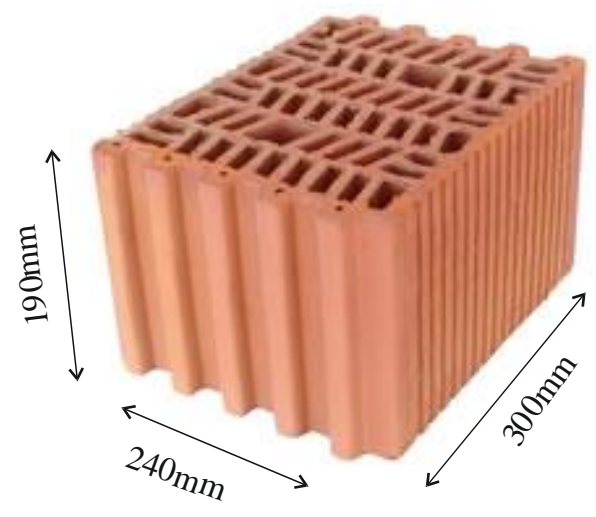

(b)

Figure 1: Clay bricks produced at Preceram: (a) Traditional brick (TB) (horizontal holes); (b) Original thermal brick (OB) and Ecothermal brick (EB) (vertical holes).

\section{Materials ANd Methods}

\subsection{Production Process}

The aluminium waste was from the Lacoviana industry (Portugal), in as-produced form, like a gel, composed by a nanostructured material with $77 \%$ of water content. Clay from production line of the brick plant at Preceram industry (Portugal), was used previously mixed and homogenized in the plant, with $13 \%$ of water content. These materials were characterized determining chemical composition (see Table 1), mineralogical composition, particle size distribution, 
thermal behaviour analysis. On the laboratory pilot line, sludge was dried at $110^{\circ} \mathrm{C}$ for $24 \mathrm{~h}$ and disaggregated on an automatic mortar. Samples were prepared approaching, as best as possible, to the conventional ceramic process. It were extruded specimens of clay with and without $5 \%$ wt. of aluminium sludge then fired $\left(3^{\circ} \mathrm{C} / \mathrm{min}, 2 \mathrm{~h}\right.$ landing at max. temperature, $950^{\circ} \mathrm{C}$ ) for ceramics. Results and discussion are presented in Marques, Neto, Grilo, Vieira, \& Júlio, (2012).

Table 1 - Chemical composition of raw materials (\%)

\begin{tabular}{ccc}
\hline Raw Material & Clay & Al-sludge \\
\hline $\mathrm{SiO}_{2}$ & 71.39 & 0.95 \\
$\mathrm{Al}_{2} \mathrm{O}_{3}$ & 12.12 & 51.88 \\
$\mathrm{Fe}_{2} \mathrm{O}_{3}$ & 3.59 & 0.12 \\
$\mathrm{CaO}$ & 1.04 & 0.34 \\
$\mathrm{MgO}$ & 1.19 & 0.3 \\
$\mathrm{~K}_{2} \mathrm{O}$ & 2.09 & $<0.03$ \\
$\mathrm{Na}_{2} \mathrm{O}$ & $<0.20$ & 0.91 \\
$\mathrm{MnO}$ & 0.05 & - \\
$\mathrm{LOI}$ & 7.49 & 45.92 \\
$\mathrm{~S}$ & - & 1.9 \\
\hline
\end{tabular}

The full scale test presented herein consisted on the production of 10 tons of ecological thermal bricks (EB) at the brick plant, Preceram. 5\% wt. of as-produced sludge was previously desagglomerated in a blender, adding plus $40 \%$ wt. of water. Then, the sludge and the clay were mixed in the mill integrated on the bricks production cycle, following all the remaining stages. All remaining plant parameters were kept unchanged. Tests were performed with both the commercial brick by Preceram (TB and $\mathrm{OB}$ ), used to serve as reference, and the EB, incorporating aluminium anodizing sludge.

\subsection{Clay bricks' physical properties}

$\mathrm{TB}, \mathrm{OB}$ and $\mathrm{EB}$ dimensional and physical properties were firstly addressed, given their influence on the mechanical properties of both bricks and masonry walls, and also to allow their classification for structural purposes according to Eurocode 6 (ECS, 2003). Figure 1 shows the nominal dimensions, height, width and depth, of both traditional and thermal bricks, produced by Preceram. These dimensions were reassessed, according to EN 772-16 (ECS, $2000 \mathrm{~b})$. Several experimental tests were then performed following the relevant standards, in order to compare the following physical properties of the bricks considered: real and apparent density (ECS, 2002b), water absorption (ECS, 1998), and voids percentage (ECS, 2000a). 


\subsection{Mechanical properties of raw material}

A sample of 8 specimens of both ceramic materials (with and without aluminium sludge addition) with the following mean dimensions $95 \times 24.5 \times 57.7 \mathrm{~mm}^{3}$ was produced. A Shimadzu Autograph AG-IS, with a maximum capacity of $100 \mathrm{kN}$, was used for testing the specimens in compression (see Figure 2).

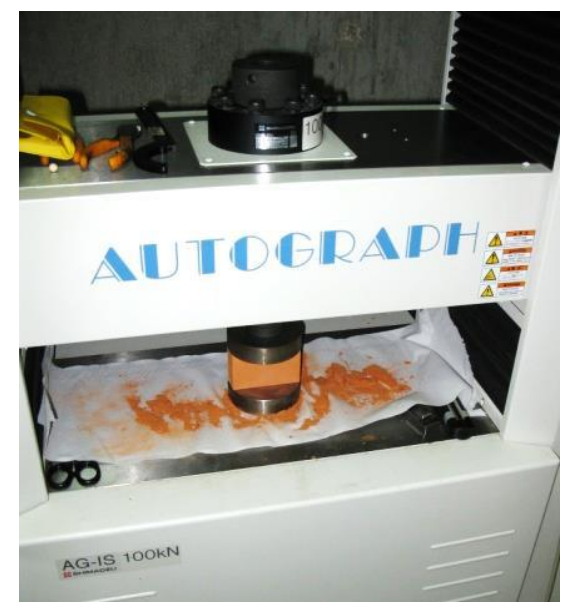

(a)

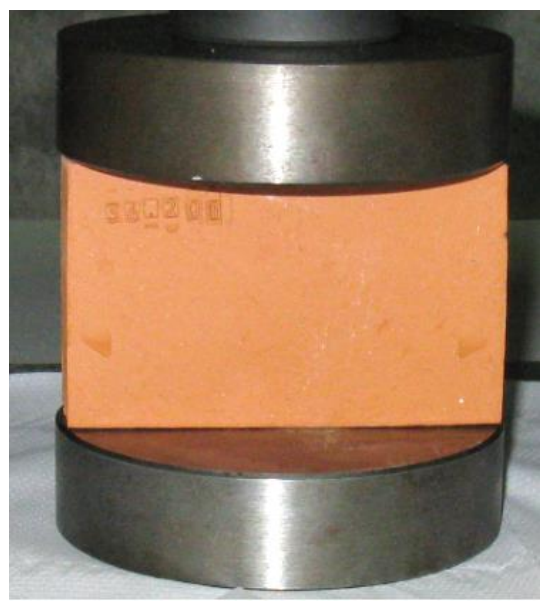

(b)

Figure 2: Specimens compressive test: (a) Shimadzu Autograph AG-IS; (b) 95x24.5x57.7mm specimens.

The opposite $95 \times 24.5 \mathrm{~mm}^{2}$ sides of the specimens were first regularized and polished and then submitted to an axial force imposed with displacement control at a rate of $1 \mathrm{~mm}$ per minute. These compressive tests were carried out up to failure of the specimens.

\subsection{Bricks' mechanical properties}

The mechanical properties of bricks, in particular the compressive strength measured on each of the three faces were assessed according to EN 772-1 (ECS, 2002a). Faces numbers were defined according to bricks position on an assemble masonry wall, Figure 3. Therefore, for both bricks geometries, Face 1 respects to the horizontal interface, Face 2 corresponds to the assembled wall plane, and Face 3 indicates the vertical interface. To be noted that Face 2 can also be used as horizontal interface for traditional bricks. These are usually assembled using mortar on both Faces 1 and 3 , while thermal bricks are assembled using just mortar in Face 1 and a male/female connection across Face 3, Figure 3 (b). A set of 6 specimens was tested under compression for each type and face, resulting in a total of 54 tests, corresponding to 18 bricks tested for each type (TB, OB and $\mathrm{EB})$. 


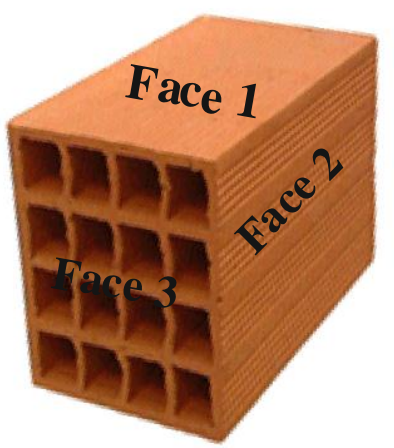

(a)

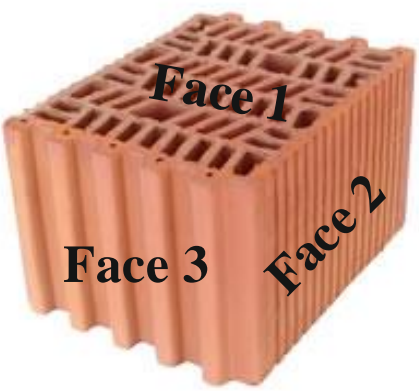

(b)

Figure 3: Identification of bricks' faces for compression test: (a) TB; (b) OB and EB.

Bricks were prepared for the test by correcting the loading faces with a tolerance of $0.1 \%$ within the plane and $1 \%$ for the parallelism between opposite faces. This preparation was completed using a mechanical rectifier, as depicted in Figure 4, for both OB and EB specimens.

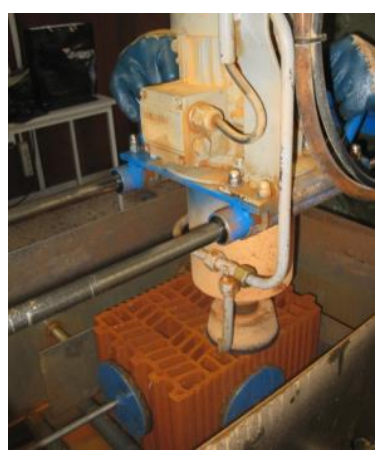

(a)

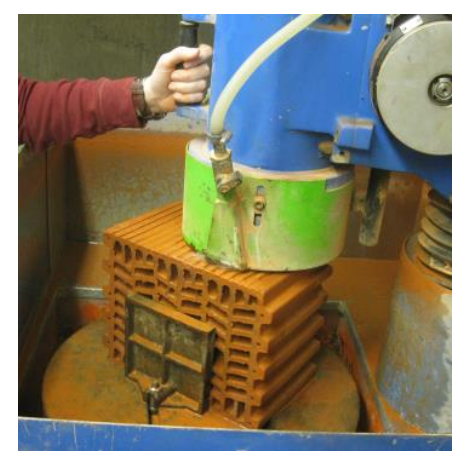

(b)

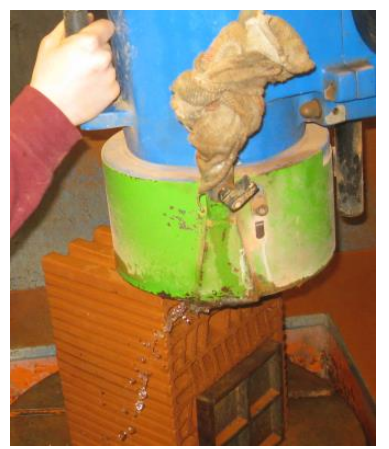

(c)

Figure 4: Original and Ecological brick correction of: (a) Face 1; (b) Face 2; (c) Face 3.

Afterward, bricks were dried at a temperature of $105^{\circ} \mathrm{C}$, until no weight variation was observed, and then cooled down at ambient temperature.

The loading rate for the compression test was defined according to EN 772-1 (ECS, 2002a), thus depending on the expected compressive strength and the gross area, $A_{0}$, of the loaded brick face. Considering that the compressive strength was expected to be lower than $10 \mathrm{MPa}$, a loading rate leading to a stress increase of $0.05 \mathrm{MPa} / \mathrm{s}$ was adopted.

\subsection{Mechanical properties of masonry wall specimens}

\subsubsection{Mortar}

The strength of masonry in both tension and shear is significantly lower than that in compression (Alecci, Fagone, Rotunno, \& De Stefano, 2013; Monteagudo, Casati, \& Gálvez, 2015). In addition, it is highly dependent on the mechanical properties of the mortar adopted to assemble the bricks, which is applied on both vertical and horizontal 
interfaces when TB are used or just on horizontal interfaces when EB are adopted. For this reason, before analysing the results of tests performed with masonry wall specimens, the characterization of the assembling mortar is presented.

A M5 premixed commercial mortar, recommended by the bricks' manufacturer, was selected and its characteristics experimentally assessed. The mortar's physical properties, in particular the real density and the consistency, were determined according to EN 998-2 (ECS, 2010), EN 1015-2 (ECS, 1999a), and EN 1015-3 (ECS, 1999b), respectively. Flexural and compressive strengths were tested according to EN 1015-11 (ECS, 1999c). A set of 3 standardized specimens was produced, tested 28 days later (see Figure 5), and finally classified according to Eurocode 6 (ECS, 2003).

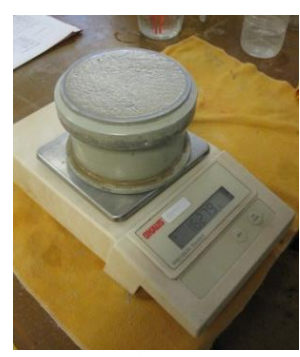

(a)

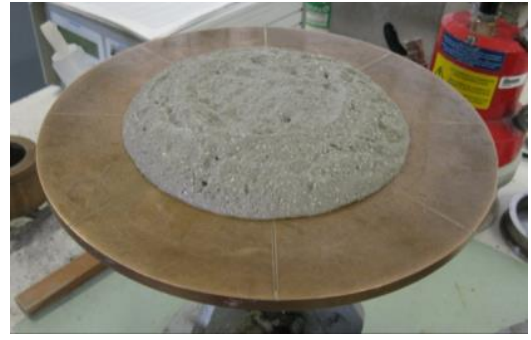

(b)

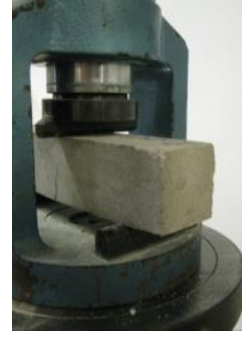

(c)

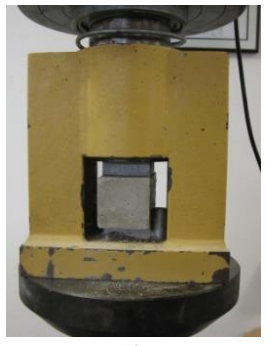

(d)

Figure 5: Physical and mechanical characterization of the mortar: (a) Real density 1; (b) Consistency; (c) Flexural strength; (d) Compressive strength.

\subsubsection{Compressive strength of masonry wall specimens}

Masonry compressive testing were executed on prismatic specimens composed by three bricks and two mortar interfaces, as depicted in Figure 6. For both TB and EB loading face was defined as Face 1, that primarily subjected to gravity loads on an assembled masonry wall.

Specimens assembled with TB and EB were produced according to EN 1052-3 (ECS, 2005) and for the latter continuous and discontinuous (horizontal) interfaces were used. Discontinuous joints consisted on two mortar lines at the bricks borders, each one with $80 \mathrm{~mm}$ of width, thus corresponding to a third of the brick width. Discontinuous interfaces are recommended by the bricks' manufacturer in order to achieve the best thermal performance. In addition, aiming at avoiding cracks or localized crushing of bricks' loaded faces, and according to (Mohamad, 2007), a 10 mm thickness grout layer was applied on top of the faces in direct contact with the hydraulic jack plates, Figure 7. 


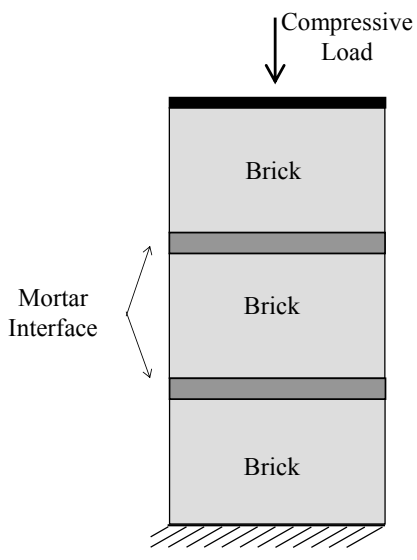

Figure 6: Load setup for the compressive tests.
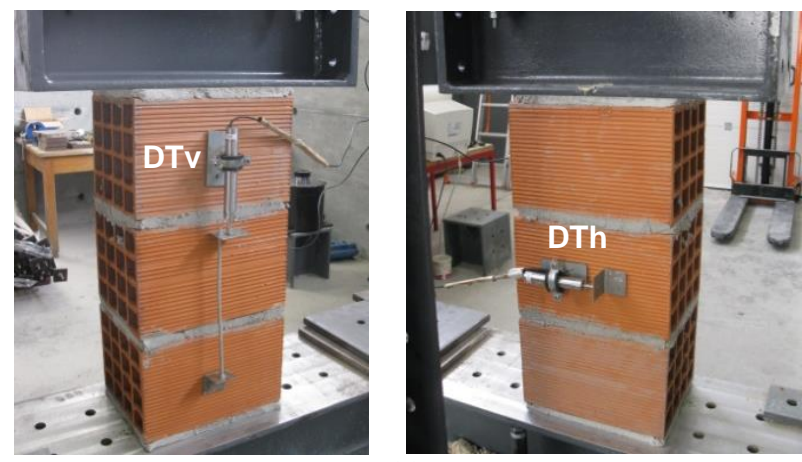

(a)

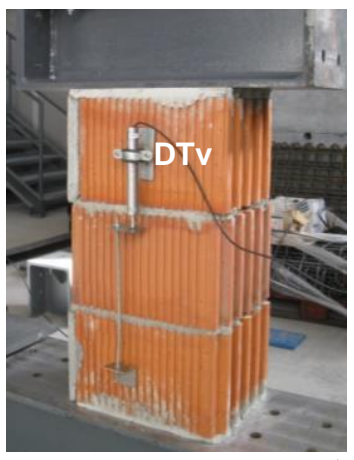

(b)

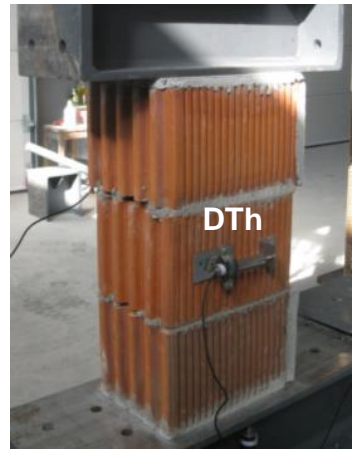

Figure 7: Masonry wall specimens for compression test: (a) TB; (b) EB.

Each specimen was monitored with vertical (DTv) and horizontal (DTh) displacement transducers so that the Young's modulus and the Poisson coefficient could be estimated. A $300 \mathrm{kN}$ load cell was used to measure testing force. Compression tests consisted of two stages. In the first stage, five load-unload cycles were applied with increasing load. The maximum load of each cycle was defined as a percentage of the expected compressive strength, $f_{k}$, of the masonry wall, given by Equation (1) ECS, 2003):

$$
f_{k}=K \times f_{b}^{0.7} \times f_{m}^{0.3}
$$

where $K$ is a constant that depends on both mortar and brick types, $f_{b}$ is the compressive strength of the bricks corresponding to the loaded face, and $f_{m}$ is the compressive strength of the mortar.

For TB masonry specimens, the first two cycles (out of five) were driven up to a maximum load corresponding to $0.15 f_{k}$, and the remaining three cycles were driven up to $0.40 f_{k}$. For each cycle, the maximum load was kept constant during $30 \mathrm{~s}$. For EB masonry specimens, the same procedure was adopted, however limiting the maximum compressive stress to $0.10 f_{k}$, for the first two cycles, and to $0.20 f_{k}$, for the last three cycles. Figure 8 depicts the first stage of the 
loading test adopted to assess the masonry specimens' elastic properties. Next, the load was increased up to the specimen's failure was observed. During this last stage, a vertical displacement was imposed at a rate of $0.01 \mathrm{~mm} / \mathrm{s}$.

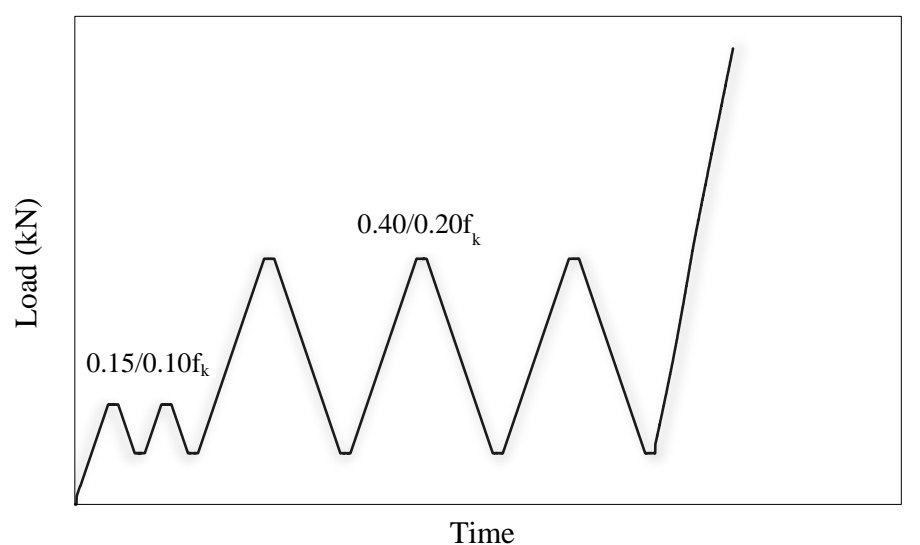

Figure 8: Loading protocol history adopted for compression tests.

The compressive strength, $f_{c}$, of each specimen, was computed according to EN 1052-1 (European Committee for Standardization, 2000c):

$$
f_{c}=\frac{F_{\max }}{A}
$$

where $F_{\max }$ is the maximum recorded force, and $A$ is the effective loaded area of the specimen. The Young's modulus was computed based on the records of the vertical displacement transducers, assuming the specimen subjected to uniform strain.

\subsubsection{Initial Shear strength of masonry wall specimens}

The shear strength of masonry wall specimens, built using traditional or thermal bricks, was assessed according to EN 1052-3 (ECS, 2005). Specimens composed of three bricks and two mortar interfaces were tested using a 3-point load setup, as shown in Figure 9. Supports were positioned under the lateral bricks, whereas the load was applied to the central brick. This test can be performed considering or not a perpendicular pre-compressive force.

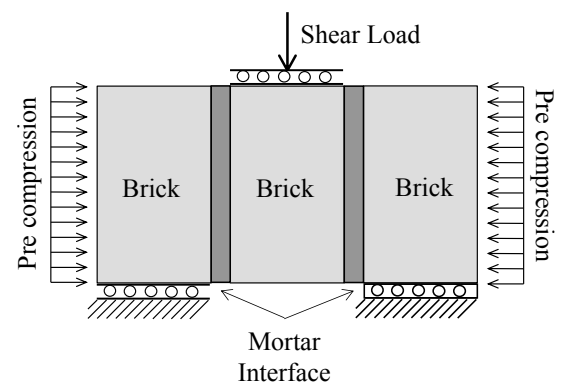

Figure 9: Shear test setup for masonry specimens. 
This test allows the assessment of the initial shear strength, including the measurement of the cohesion coefficient and friction angle. Being highly sensitive to geometric imperfections, tested specimens were carefully prepared. First, brick faces to be subjected to loads and supports were rectified, as described in section 0 , in order to obtain rigorously plane surfaces. Then, the specimens were assembled on a perfectly levelled surface using a mortar interface with $15 \mathrm{~mm}$ thickness. For the wall specimens assembled with thermal bricks, two types were produced, including either a continuous or a discontinuous mortar interface with an $80 \mathrm{~mm}$ gap corresponding to $1 / 3$ of the interface width. The latter is usually recommended for improved thermal performance, although exhibiting in this case poorer mechanical behaviour. To measure vertical displacements, a set of three displacement transducers (DTv1 to DTv3) was used, as shown in Figure 10 (a). The relative displacements of lateral bricks relatively to the central brick were measured using DTv1 and DTv3, while DTv2 was used to measure the absolute displacement of the central brick.

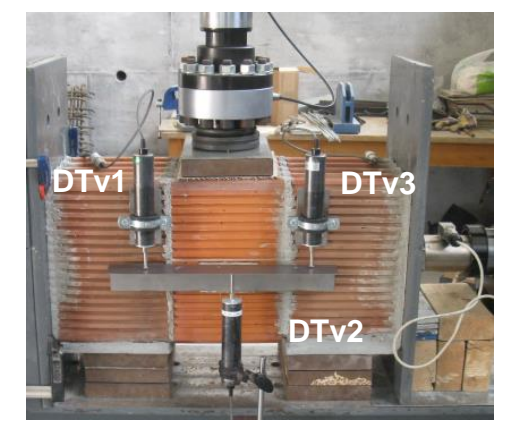

Figure 10: Displacement transducers used to measure vertical displacements.

The imposed load was measured using the inner sensor of the hydraulic jack, as well as a $300 \mathrm{kN}$ load cell. This redundancy aimed at ensuring the geometric accuracy by checking the perpendicularity of the compressive force. The vertical load was applied to the central brick with displacement control at a rate of $0.01 \mathrm{~mm} / \mathrm{s}$. The influence of perpendicular pre-compressive stresses was studied by conducting the test with different stress levels, defined according to the expected compressive strength, $f_{k}$, given by Equation (1) (ECS, 2003). Different pre-compression levels were used: $0 \%, 55 \%$ and $80 \%$ of $f_{k}$, for TB and $0 \%, 10 \%$ and $20 \%$ of $f_{k}$, or $0 \%, 20 \%$ and $30 \%$ of $f_{k}$ for EB with continuous and discontinuous joints, respectively. The adopted minimum values for the pre compression needed to be defined based on the hydraulic actuator accuracy to maintain applied pressure constant during the test. The maximum values were chosen to compare the behaviour of TB and EB masonry walls under equivalent pre-compressive stresses and similar to those expected in real situations. To keep the pre-compressive stress constant during the test, the pressure on the hydraulic actuator was carefully controlled. 
The shear strength of each specimen, $f_{v}$, was assessed according to EN 1052-3 (ECS, 2005), and Equation (3):

$$
f_{v}=\frac{F_{\max }}{2 A}
$$

where, $F_{\text {max }}$ is the maximum imposed load and $A$ is the effective normal area of the specimen, to which the precompressive load is applied.

\section{RESUlTS AND DISCUSSION}

As referred, the new eco-efficient material was obtained by adding $5 \%$ in weight of aluminium sludge, in nanocrystalline form, to the original clay. The thermal characterization of this added clay has been published in (Santos et al., 2015). A $15.6 \%$ reduction in the thermal conductivity was obtained compared to the original raw material. Regarding the final product, the clay bricks, a $10 \%$ improvement relatively to the original thermal transmittance was attained. In the present paper, the effect on the mechanical properties of eco-thermal bricks of incorporating aluminium sludge is evaluated.

Table 2 shows the mean values obtained with a sample of 6 specimens. Mean dimensions of EB resulted slightly below those of $\mathrm{OB}$ with the major difference below $3 \%$ for the brick height.

Table 2 -Brick's dimensions

\begin{tabular}{ccccccc}
\hline \multirow{2}{*}{ Geometry } & \multicolumn{2}{c}{ Height } & \multicolumn{2}{c}{ Width } & \multicolumn{2}{c}{ Depth } \\
\cline { 2 - 7 } & $\begin{array}{c}\text { Mean } \\
(\mathbf{m m})\end{array}$ & $\operatorname{COV}(\boldsymbol{\%})$ & $\begin{array}{c}\text { Mean } \\
(\mathbf{m m})\end{array}$ & $\operatorname{COV}(\boldsymbol{\%})$ & $\begin{array}{c}\text { Mean } \\
(\mathbf{m m})\end{array}$ & $\operatorname{COV}(\boldsymbol{\%})$ \\
\hline Traditional (TB) & 191.0 & 0.33 & 290.0 & 0.34 & 218.4 & 0.25 \\
Original Thermal (OB) & 191.4 & 0.67 & 298.0 & 0.23 & 244.4 & 0.32 \\
Eco Brick (EB) & 186.0 & 0.36 & 296.0 & 0.20 & 238.0 & 0.33 \\
\hline
\end{tabular}

Physical properties of TB, OB and EB are presented in Table 3.

Table 3 -Brick's physical properties

\begin{tabular}{|c|c|c|c|c|c|c|}
\hline \multirow{2}{*}{ Properties } & \multicolumn{2}{|c|}{ Traditional Brick (TB) } & \multicolumn{2}{|c|}{ Original Thermal Brick (OB) } & \multicolumn{2}{|c|}{ Eco Brick (EB) } \\
\hline & Mean & $\operatorname{COV}(\%)$ & Mean & $\operatorname{COV}(\%)$ & Mean & $\operatorname{COV}(\%)$ \\
\hline Real Density $\left[\mathrm{kg} / \mathrm{m}^{3}\right]$ & 2040 & 0.45 & 2030 & 0.84 & 1920 & 0.17 \\
\hline Apparent Density $\left[\mathrm{kg} / \mathrm{m}^{3}\right]$ & 665 & 0.75 & 890 & 1.30 & 770 & 0.51 \\
\hline Water absortion [\%] & 8.7 & 2.40 & 9.5 & 0.87 & 12.5 & 1.26 \\
\hline Voids percentage [\%] & 68 & 0.37 & 56 & 1.58 & 60 & 0.25 \\
\hline
\end{tabular}

Real density of EB was lower than that of both TB and OB, whereas water absorption was higher, due to the higher porosity of the raw material of EB, given the nature of the added nano-crystalline sludge. This fact can explain the improved thermal performance of EB masonry walls (Santos et al., 2015), as a result of the lower conductivity of the 
raw material incorporating the aluminium sludge and, consequently, of the expected lower thermal transmittance of the assembled wall.

The first set of mechanical tests was carried out to characterize the compressive strength of the raw material. Similar failure modes were obtained for all specimens independently of having been produced with or without aluminium sludge addition (Figure 11 (a) and (b), respectively).

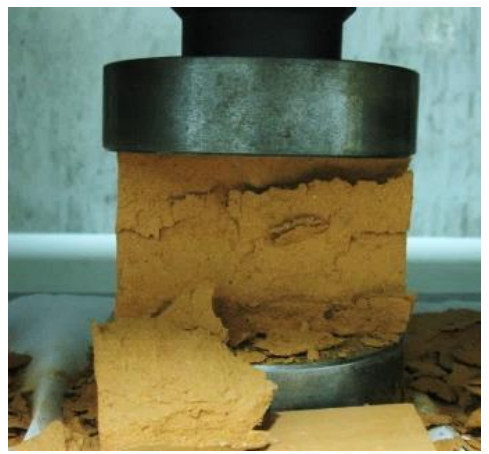

(a)

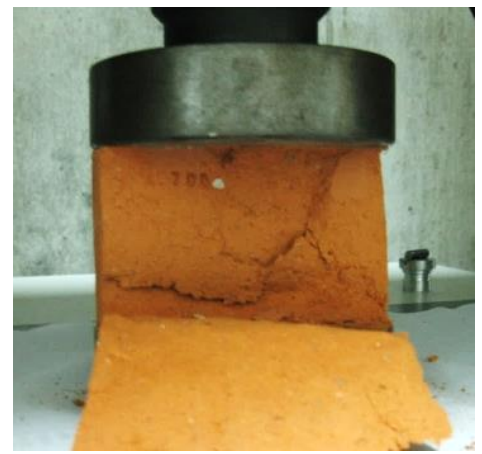

(b)

Figure 11: Specimens failure: (a) without aluminium sludge; (b) with aluminium sludge.

The obtained mean values of the ultimate load and stress are presented in Table 4.

Table 4 - Assessed mean values for compressive strength of original and additivated ceramic material

\begin{tabular}{cccc}
\hline Raw Material & $\begin{array}{c}\text { Ultimate Load } \\
(\mathbf{k N})\end{array}$ & $\begin{array}{c}\text { Ultimate Stress } \\
(\mathbf{M P a})\end{array}$ & $\mathbf{C O V}(\boldsymbol{\%})$ \\
\hline Original clay & 30.62 & 13.29 & 12.4 \\
Clay with 5\% al. sludge & 27.96 & 12.52 & 15.0 \\
\hline
\end{tabular}

It was observed a slight decrease (of approximately 5\%) of the compressive strength for specimens produced with the addition of aluminium sludge, which can be explained by the reduced density of the raw material (see Table 3).

Figure 12 and Figure 13 illustrate the typical failure modes obtained for TB and for both OB and EB, respectively. It has to be stressed that $\mathrm{OB}$ and EB exhibited similar failure modes in each tested face.

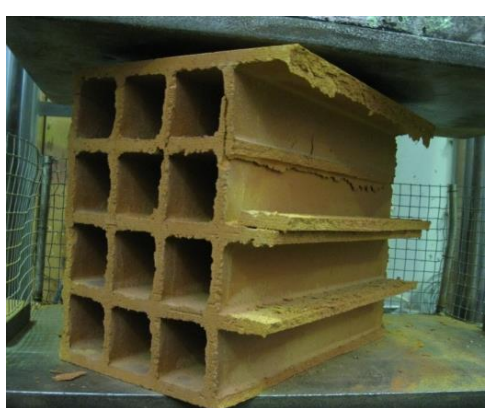

(a)

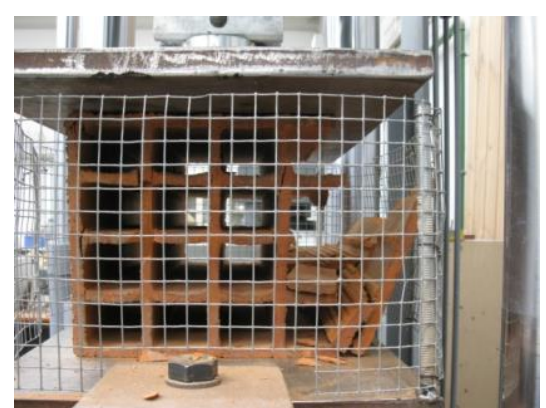

(b)

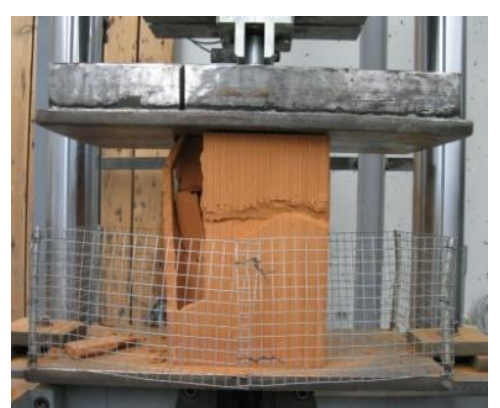

(c)

Figure 12: Failure modes obtained for TB: (a) Face 1; (b) Face 2; (c) Face 3. 


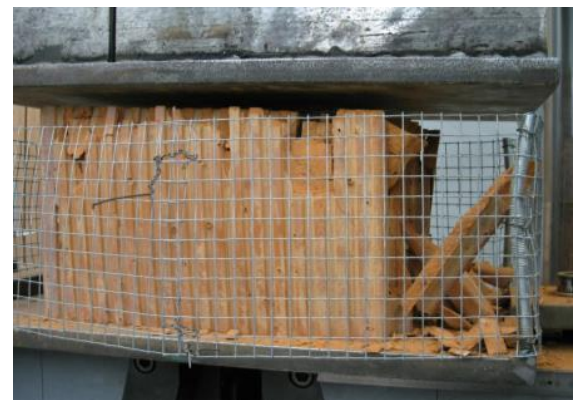

(a)

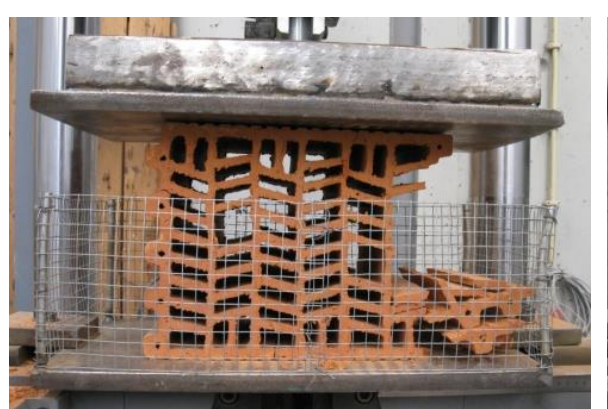

(b)

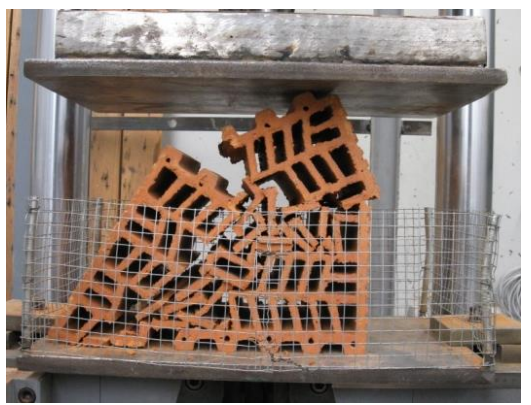

(c)

Figure 13: Failure modes obtained for both OB and EB: (a) Face 1; (b) Face 2; (c) Face 3.

In Table 5, the mean values of the compressive strength obtained for each brick type and face are presented. It can be seen that the mechanical performance of thermal bricks (both OB and EB) is much higher than that of traditional bricks, when compression is applied to Face 1, quite similar when applied to Face 2, and significantly lower when applied to Face 3. As mentioned, for thermal bricks Face 1 corresponds to the horizontal interface on an assembled wall, being therefore subjected to compressive loads, whereas for traditional bricks, either Face 1 or Face 2 can be loaded in compression. If compression is applied to Face 3, minimum and maximum compressive strengths are registered, respectively for thermal and traditional bricks. In this case performance of traditional bricks is much better than that of thermal bricks, as compression is parallel to brick septa. However, it should be highlighted that, for thermal bricks, Face 3 corresponds to a dry interface. Therefore, when assembling a masonry wall, no mortar is needed in this face and, due to male/female connection between adjacent bricks, null or negligible compression stresses are expected to occur in this face. The applied load on Face 3 is perpendicular to the brick septa, which can also explain the lower strength when compared to the remaining faces of thermal bricks, and Face 3 of traditional bricks.

Table 5 - Mean values for compressive strength of TB, OB and EB

\begin{tabular}{cccccccccc}
\hline \multirow{2}{*}{$\begin{array}{c}\text { Brick } \\
\text { type }\end{array}$} & $\begin{array}{c}\text { Ultimate } \\
\text { Load }(\mathbf{k N})\end{array}$ & $\begin{array}{c}\text { Ultimate } \\
\text { Stress (MPa) }\end{array}$ & $\begin{array}{c}\text { COV } \\
(\boldsymbol{\%})\end{array}$ & $\begin{array}{c}\text { Ultimate } \\
\text { Load (kN) }\end{array}$ & $\begin{array}{c}\text { Cltimate } \\
\text { Stress (MPa) }\end{array}$ & $\begin{array}{c}\text { COV } \\
(\boldsymbol{\%})\end{array}$ & $\begin{array}{c}\text { Ultimate } \\
\text { Load (kN) })\end{array}$ & $\begin{array}{c}\text { Ultimate Stress } \\
(\mathbf{M P a})\end{array}$ & $\begin{array}{c}\text { COV } \\
(\boldsymbol{\%})\end{array}$ \\
\hline TB & 99.4 & 1.8 & 15.2 & 99.3 & 1.6 & 14.0 & 210.5 & 5.5 & 10.1 \\
OB & 515.7 & 7.3 & 6.8 & 117.8 & 2.1 & 15.4 & 14.0 & 0.3 & 5.7 \\
EB & 445.7 & 6.3 & 7.6 & 97.6 & 1.8 & 16.8 & 12.8 & 0.3 & 5.8 \\
\hline
\end{tabular}

Comparing the compressive strengths of $\mathrm{OB}$ and $\mathrm{EB}$, it can be stated that for compressive loads applied to Faces 1 and 2, thus parallel to webs and shells of bricks' units, EB shows a decrease of $15 \%$, probably as a result of the $5 \%$ decrease of the compressive strength of the raw material observed when an addiction of $5 \%$ of aluminium sludge was considered. Although less significant, this difference can also be partially explained by the smaller dimensions of EB when 
compared to OB (see Table 2 ). If compression is applied to Face 3, strengths of both OB and EB are similar, being this result irrelevant for the reasons mentioned before.

Lastly, it can be stated that, although the mechanical properties of EB are slightly lower those of OB, the difference is not significant, and compared to TB, in particular results regarding Face 1 (the one primarily subjected to compression), EB is far better than TB.

As observed, the mechanical properties of $\mathrm{OB}$ and $\mathrm{EB}$ are very similar and, thus, just the latter was used in the experimental study defined to characterise mechanical properties of masonry and compared with the performance of TB.

Physical and mechanical properties of the masonry assembling mortar are presented in Table 6 and Table 7 , respectively, showing that classification according to the experimental tests is the same announced by the mortar manufacturer.

Table 6 - Mortar's physical properties

\begin{tabular}{ccc}
\hline $\begin{array}{c}\text { Real } \\
\text { Density } \\
{\left[\mathrm{kg} / \mathbf{m}^{3}\right]}\end{array}$ & $\begin{array}{c}\text { Consistency } \\
{[\mathbf{c m}]}\end{array}$ & $\begin{array}{c}\text { Voids Percentage } \\
{[\%]}\end{array}$ \\
\hline 1820 & 16 & 20 \\
\hline
\end{tabular}

Table 7 - Mortar mechanical properties

\begin{tabular}{ccc}
\hline $\begin{array}{c}\text { Flexural } \\
\text { Strength } \\
{[\mathrm{MPa}]}\end{array}$ & $\begin{array}{c}\text { Compressive } \\
\text { Strength } \\
{[\mathrm{MPa}]}\end{array}$ & $\begin{array}{c}\text { Mortar Class } \\
\text { (according to } \\
\text { ECS, 2003) }\end{array}$ \\
\hline 2.2 & 5.0 & M5 \\
\hline
\end{tabular}

Results of the compression tests of the masonry specimens are presented in Table 8 for TB and EB either with continuous or discontinuous mortar joints. The scatter of the results of the horizontal displacement transducers did not allow the computation of the Poisson coefficient.

Table 8 - Compression test Results

\begin{tabular}{cccc}
\hline $\begin{array}{c}\text { Masonry } \\
\text { Brick }\end{array}$ & $\begin{array}{c}\boldsymbol{F}_{\max } \\
(\mathbf{k N})\end{array}$ & $\begin{array}{c}\boldsymbol{f}_{\boldsymbol{c}} \\
(\mathbf{k P a})\end{array}$ & $\begin{array}{c}\mathbf{E} \\
(\mathbf{M P a})\end{array}$ \\
\hline \multirow{2}{*}{ TB } & 68 & 1063 & 206 \\
& 93 & 1453 & 197 \\
& 73 & 1143 & 188 \\
\hline \multirow{2}{*}{ EB Disc. Joint } & 156 & 2303 & 295 \\
& 176 & 2603 & 317 \\
\multirow{2}{*}{ EB Cont. } & 178 & 2630 & 312 \\
Joint & 254 & 3752 & 309 \\
& 243 & 3598 & 312 \\
\hline
\end{tabular}


In what concerns to the failure modes, these specimens, when axially compressed, develop perpendicular compressive stresses at the mortar interface, due to Poisson effect and horizontal expansion of the latter (Figure 14). This expansion is controlled by the bricks, which by equilibrium develop horizontal tensile stresses. According to different previous studies (Hamid \& Drysdale, 1979; Cheema \& Klingner, 1986; Garcia, 2000; Haach, 2009), the following failure modes are likely to occur in masonry wall specimens tested in compression: (i) Mode 1: Crushing of the mortar joint; (ii) Mode 2: Cracking of bricks; (iii) Mode 3: Crushing of bricks; (iv) Mode 4: A combination of the previous.

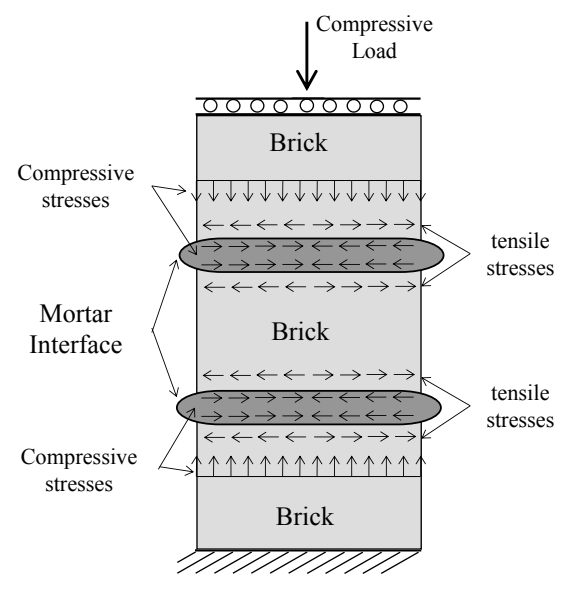

Figure 14: Resulting stresses on an axially compressed prismatic specimen.

Observed failure modes are presented in Figure 15. For TB masonry wall specimens, cracks occurring at the bricks' ends were primarily observed, followed by brick crushing. For EB masonry wall specimens, first several vertical cracks developed, some of these along all the specimens' height, and then, after reaching the peak load, collapse occurred with specimens' crushing. In all cases, it was clear that brick cracking started at the brick/mortar interface, which induced the specimen's failure, corroborating what is stated in previous studies (Gouveia \& Lourenço, 2007; Kaushik, Rai, \& Jain, 2007). 


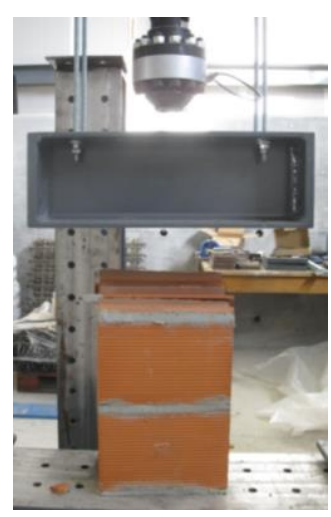

(a)

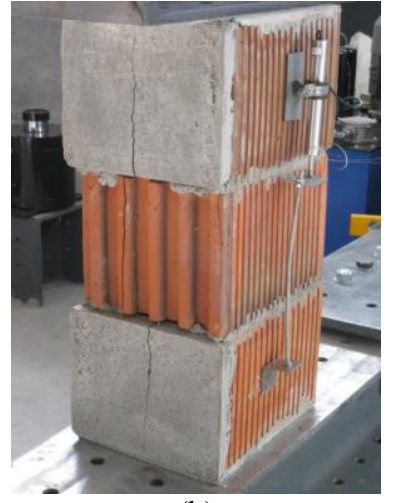

(b)

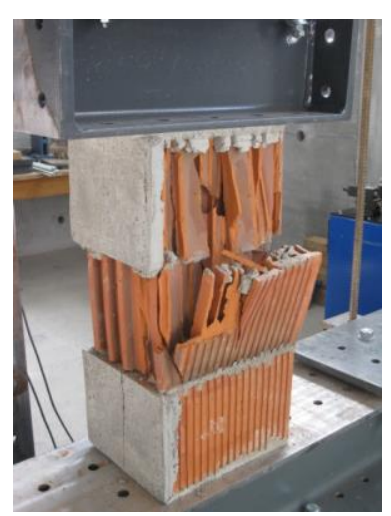

(c)

Figure 15: Observed failure modes of masonry wall specimens tested in compression: (a) TB; (b) EB; (c) EB.

In Table 9 the mean values for compressive strength and Young's modulus of tested specimens are given. The results analysis leads to the following conclusions: (i) TB masonry wall specimens exhibit a much reduced strength and a significantly higher deformability than those assembled with EB, and (ii) regarding the latter, those with continuous interfaces show both higher strength and stiffness.

Table 9 - Mean values for specimen's compressive strength and Young modulus

\begin{tabular}{cccc}
\hline $\begin{array}{c}\text { Masonry } \\
\text { Brick }\end{array}$ & $\begin{array}{c}\boldsymbol{F}_{\max } \\
(\mathbf{k N})\end{array}$ & $\begin{array}{c}\boldsymbol{f}_{\boldsymbol{c}} \\
(\mathbf{k P a})\end{array}$ & $\begin{array}{c}\mathbf{E} \\
(\mathbf{M P a})\end{array}$ \\
\hline TB & 78 & 1220 & 197 \\
\hline EB Disc. Int. & 170 & 2512 & 308 \\
\hline EB Cont. Int. & 248 & 3675 & 313 \\
\hline
\end{tabular}

There is a strong relationship between the compressive strength of the masonry wall specimens and the type of brick adopted to assemble these. EB masonry wall specimens sustained approximately the double of the load supported by the TB counterpart, when discontinuous mortar interfaces were adopted, and approximately three times more, when continuous mortar interfaces were used. The lower compressive strength of TB bricks compared to EB bricks, approximately $30 \%$ lower when Face 1 is loaded (see Table 5), surely contributed for the significantly better performance of EB masonry walls. The reduced strength of TB specimens can be explained by comparing the bricks strength per face presented in Table 5. Compressive strength of TB is approximately $30 \%$ of that of EB, when Face 1 is loaded. The effect of a continuous mortar joint is insignificant for the specimen Young's Modulus but can increase compressive strength of thermal specimens in almost 50\%, although leading to a worse thermal behaviour, as referred to.

A generic load vs. displacement curve of the central brick is shown in Figure 16, obtained with shear tests performed with and without a pre-compressive force. Pre-compressed specimens tend to exhibit higher strength than those without 
pre-compression, as stated in the literature (Abdou, Saada, Meftah, \& Mebarki, 2006; Chaimoon \& Attard, 2009; Haach, 2009). In the latter case, after the maximum load have been reached, the shear strength goes down reaching negligible values, while in the former case, due to friction, a significant residual strength is maintained.

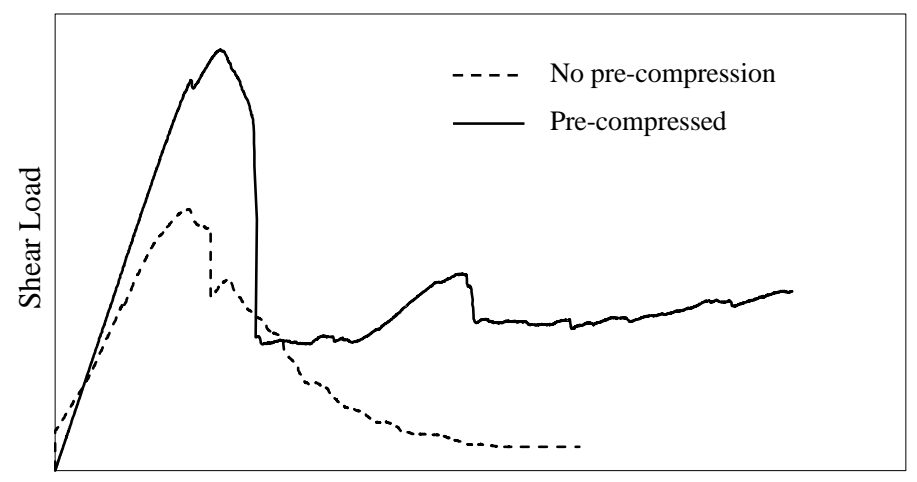

Central Brick displacement

Figure 16: Generic load displacement curve of the shear test.

Table 10 summarizes results obtained for the masonry wall specimens assembled with TB or EB, using for the latter both continuous and discontinuous mortar interfaces.

Table 10 - Pre-compression levels applied to masonry wall specimens

\begin{tabular}{|c|c|c|c|c|}
\hline $\begin{array}{c}\text { Masonry } \\
\text { Brick }\end{array}$ & $\begin{array}{c}\text { Pre-compression } \\
\text { Stress Level } \\
\left(\% f_{k}\right) \\
\end{array}$ & $\begin{array}{c}\text { Pre-compressive } \\
\text { Stress } \sigma_{d} \\
(\mathrm{MPa}) \\
\end{array}$ & $\begin{array}{c}\text { Max. Load } \\
\boldsymbol{F}_{\max } \\
(\mathbf{k N}) \\
\end{array}$ & $\begin{array}{c}\text { Shear Strength } \\
\boldsymbol{f}_{v} \\
(\mathrm{MPa}) \\
\end{array}$ \\
\hline \multirow{7}{*}{ TB } & \multirow[t]{3}{*}{ 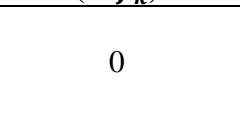 } & \multirow{3}{*}{0.00} & 25.0 & 0.19 \\
\hline & & & 38.5 & 0.30 \\
\hline & & & 32.5 & 0.25 \\
\hline & \multirow[b]{2}{*}{55} & \multirow{2}{*}{0.47} & 60.0 & 0.47 \\
\hline & & & 75.5 & 0.58 \\
\hline & \multirow{2}{*}{80} & \multirow{2}{*}{0.70} & 75.5 & 0.59 \\
\hline & & & 76.0 & 0.59 \\
\hline \multirow{10}{*}{$\begin{array}{c}\text { EB with } \\
\text { Discontinuous } \\
\text { Joint }\end{array}$} & \multirow{2}{*}{0} & \multirow{2}{*}{0.00} & 32.0 & 0.23 \\
\hline & & & 26.0 & 0.19 \\
\hline & \multirow{5}{*}{20} & \multirow{4}{*}{0.51} & 55.0 & 0.40 \\
\hline & & & 70.0 & 0.51 \\
\hline & & & 50.0 & 0.36 \\
\hline & & & 57.0 & 0.41 \\
\hline & & \multirow{4}{*}{0.73} & 66.0 & 0.48 \\
\hline & \multirow{3}{*}{30} & & 69.0 & 0.50 \\
\hline & & & 70.0 & 0.51 \\
\hline & & & 65.0 & 0.47 \\
\hline \multirow{9}{*}{$\begin{array}{c}\text { EB with } \\
\text { Continuous } \\
\text { Joint }\end{array}$} & \multirow{2}{*}{0} & \multirow{2}{*}{0.00} & 40.0 & 0.29 \\
\hline & & & 30.0 & 0.22 \\
\hline & \multirow{4}{*}{10} & \multirow{3}{*}{0.36} & 60.0 & 0.44 \\
\hline & & & 75.0 & 0.55 \\
\hline & & & 60.0 & 0.48 \\
\hline & & \multirow{4}{*}{0.73} & 80.0 & 0.58 \\
\hline & \multirow{3}{*}{20} & & 100.0 & 0.73 \\
\hline & & & 73.0 & 0.53 \\
\hline & & & 74.0 & 0.54 \\
\hline
\end{tabular}


The obtained shear strength was also plotted versus the applied pre-compression level, as depicted in Figure 17. The friction angle was obtained from the regression line slope.

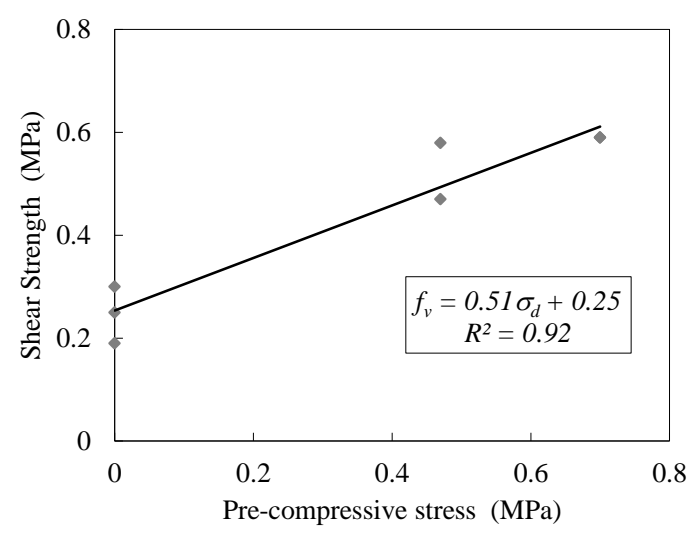

(a)

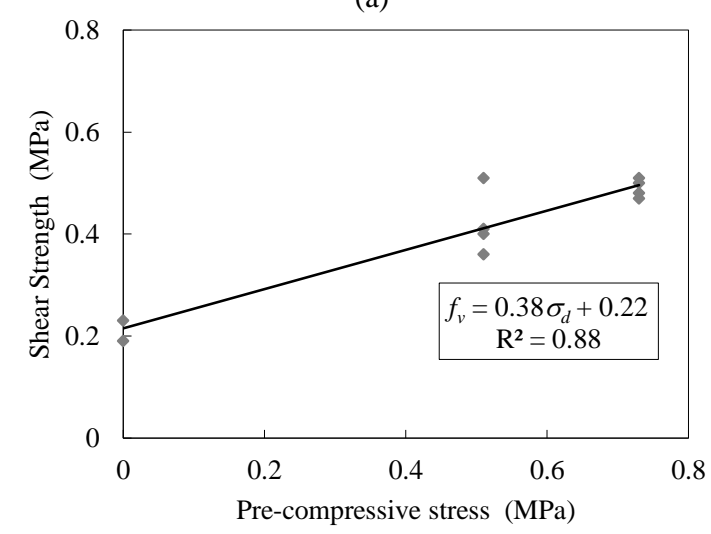

(b)

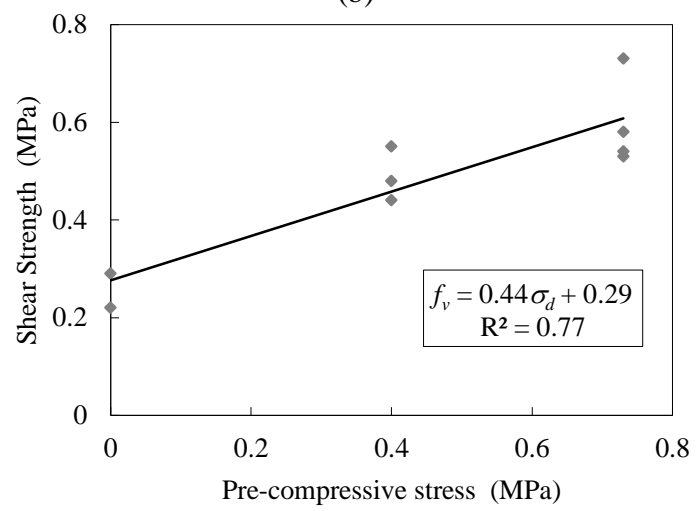

(c)

Figure 17: Shear strength as a function of pre-compression level for masonry wall specimens assembled with: (a) TB; (b) EB with discontinuous mortar interfaces; (c) EB with continuous mortar interfaces.

According to Marčiukaitis \& Valivonis, (2000), Tomaževič, (2008) and Hak, Morandi, Magenes, \& Sullivan, (2012), the following failure modes are likely to occur for the masonry wall specimens tested: (i) Mode 1: Shear failure at one or both brick/mortar interfaces; (ii) Mode 2: Shear failure at the mortar; (iii) Mode 3: Shear failure at the brick; (iv) Mode 4: Cracking / crushing of bricks. 
The failure modes observed with the tested specimens are illustrated in Figure 18, for TB masonry wall specimens, and in Figure 19, for EB masonry wall specimens. For specimens assembled with TB, and not subjected to pre-compression, failure mode 1 was observed, Figure 18 (a). For specimens assembled with TB, and pre-compressed, failure mode 4 was observed, Figure 18 (b). Specimens assembled with EB, and not subjected to pre-compression, exhibited the same failure mode as the corresponding TB specimens, Figure 19 (a), independently of having been adopted continuous or discontinuous mortar interfaces. Specimens assembled with EB, subjected to pre-compression, and with discontinuous mortar interfaces, exhibited a combined mode 1 and 4 failure, Figure 19 (b). Specimens assembled with EB, subjected to pre-compression, and with continuous mortar interfaces, exhibited failure mode 4, Figure 19 (c).

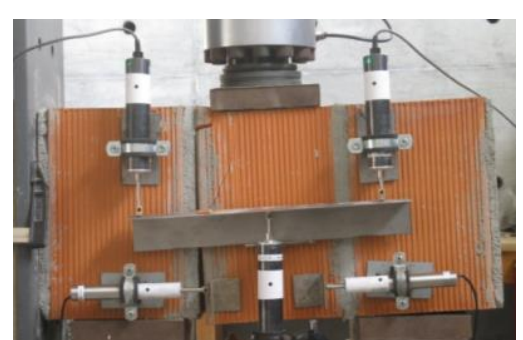

(a)

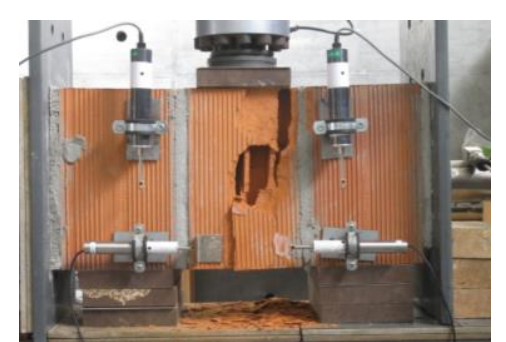

(b)

Figure 18: Failure modes observed in TB masonry wall specimens: (a) not pre-compressed; (b) pre-compressed.

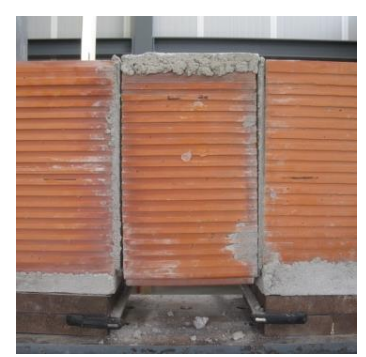

(a)

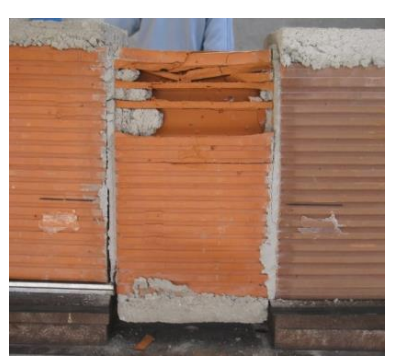

(b)

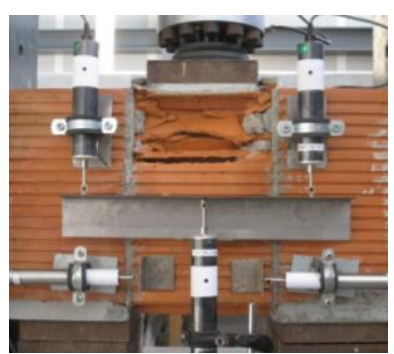

(c)

Figure 19: Failure modes observed in EB masonry wall specimens: (a) not pre-compressed; (b) pre-compressed with discontinuous interfaces; (c) pre-compressed with continuous interfaces.

Table 11 presents the mean values for the initial shear strength (uncompressed), $f_{v o}$, the friction coefficient, $\mu$, and the friction angle, $\alpha$.

Table 11 - Obtained initial shear strength, friction coefficient and friction angle

\begin{tabular}{cccc}
\hline $\begin{array}{c}\text { Masonry } \\
\text { Brick }\end{array}$ & $\boldsymbol{f}_{\boldsymbol{v o}}(\mathbf{M P a})$ & $\boldsymbol{\mu}$ & $\begin{array}{c}\boldsymbol{\alpha} \\
\boldsymbol{(}^{\mathbf{o}}\end{array}$ \\
\hline TB & 0.25 & 0.51 & 27.0 \\
\hline EB Disc. Int. & 0.22 & 0.38 & 20.1 \\
\hline EB Cont. Int. & 0.29 & 0.44 & 23.7 \\
\hline
\end{tabular}


Table 11 shows that: (i) EB masonry wall specimens with continuous interfaces present a better global shear behaviour than those with discontinuous interfaces; (ii) both the initial shear strength and the friction angle are higher in the former case, respectively $25 \%$ and $15 \%$; (iii) the friction angle is higher for specimens with continuous interfaces, assembled with TB or EB, in particular in the first case; (iv) the initial shear strength is also higher for these two cases, as shown in Figure 20, this time higher for the EB.

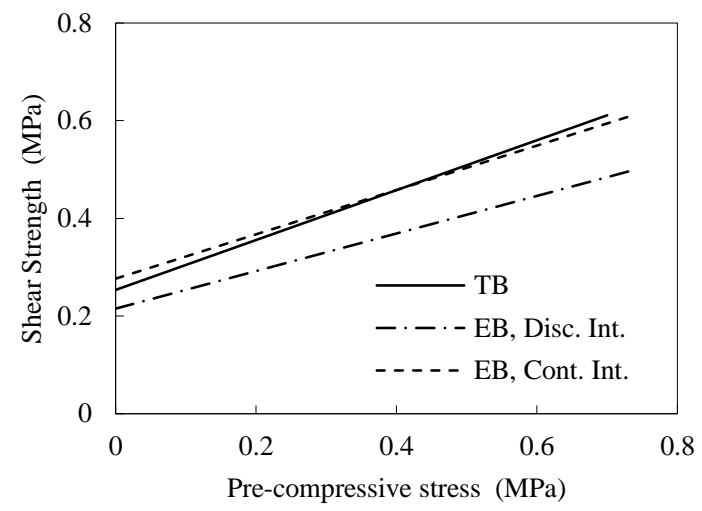

Figure 20: Comparison of shear strength for tested masonry specimens.

The initial shear strength of masonry wall specimens is highly dependent on the interface strength. This can explain the similarity between the values obtained with TB and EB masonry wall specimens with continuous interfaces and the fact that these specimens registered strength levels above specimens assembled with discontinuous interfaces.

It should be noted that the testing load was applied to brick's face 3, which is the stronger face for TB bricks, but the weaker face for EB bricks. This can be a possible reason for the higher friction angle registered for TB specimens since, for pre-compressed specimens, brick failure was frequently observed.

\section{Conclusions}

This paper presents an extensive experimental program developed to assess the mechanical properties of eco-efficient perforated clay bricks incorporating industrial nano-crystalline aluminium sludge. Tests were conducted to characterize the physical, mechanical and structural properties of the raw material, bricks, and masonry wall specimens, considering both the products available on the market as well as the innovative eco-efficient product. The following conclusions were drawn:

- The addition of $5 \%$ of nano-crystalline aluminum sludge to the ceramic raw material resulted in a $5 \%$ reduction in density, and in a 5\% reduction in compressive strength; 
- The use of this eco-efficient raw material in thermal bricks led to a $15 \%$ reduction in the compressive strength when the loading force was applied to Face 1 and Face 2;

- A strong correlation exists between the compressive strength of masonry wall specimens and both the brick's compressive strength and the mortar joint's strength; the strength of the masonry wall specimens assembled with the eco-thermal bricks considering discontinuous mortar interfaces was the double of the corresponding value when traditional bricks were used, and three times higher considering continuous interfaces;

- The shear behavior of masonry wall specimens is highly dependent on the strength of the brick to mortar interface; for this reason, the initial shear strength and the friction angle resulted higher for specimens assembled with continuous interfaces.

Taking into account the research study herein described, as well as its thermal counterpart described in (Santos et al., 2015), it can be concluded that the new eco-efficient thermal bricks, produced with the original raw material incorporating $5 \%$ of industrial nano-crystalline aluminium sludge, can be used in construction. In fact, the mechanical characteristics reduces approximately $15 \%$, but, due to their absolute strength, the latter does not limit their use, even for structural purposes.

\section{ACKNOWLEDGEMENTS}

The authors gratefully acknowledge Preceram, S.A. industry and the funding provided by the Ministério da Ciência, Tecnologia e Ensino Superior, FCT, Portugal, under the grant of PTDC/ECM-COM/2911/2012.

\section{References}

Abdou, L., Saada, R. A., Meftah, F., \& Mebarki, A. (2006). Experimental investigations of the joint-mortar behaviour. Mechanics Research Communications, 33(3), 370-384. https://doi.org/10.1016/j.mechrescom.2005.02.026

Alecci, V., Fagone, M., Rotunno, T., \& De Stefano, M. (2013). Shear strength of brick masonry walls assembled with different types of mortar. Construction and Building Materials, 40, 1038-1045. https://doi.org/10.1016/j.conbuildmat.2012.11.107

Chaimoon, K., \& Attard, M. M. (2009). Experimental and numerical investigation of masonry under three-point bending (in-plane). Engineering Structures, 31(1), 103-112. https://doi.org/10.1016/j.engstruct.2008.07.018

Cheema, T., \& Klingner, R. E. (1986). Compressive Strength of Concrete Masonry Prism. American Concrete Institute Journal, 83(1), 88-97.

Drysdale, R. G., Hamid, A. A., Baker, L. R., \& others. (1994). Masonry structures: behavior and design. Prentice Hall.

European Committee for Standardization. EN 772-7: Methods of test for masonry units. Part 7: Determination of water absorption of clay masonry damps proof course units by boiling in water (1998).

European Committee for Standardization. EN 1015-2: Methods of test for mortar for masonry. Bulk sampling of mortars and preparation of test mortars (1999). 
European Committee for Standardization. EN 1015-3: Methods of test for mortar for masonry. Determination of consistence of fresh mortar (1999).

European Committee for Standardization. EN 772-3: Methods of test for masonry units. Part 3: Determination of net volume and percentage of voids of clay masonry units by hydrostatic weighing (2000).

European Committee for Standardization. EN 772-16: Methods of test masonry units: determination of dimensions, 2 ISO 22007-2 § (2000).

European Committee for Standardization. EN 1052-1: Methods of test for masonry. Determination of compressive strength (2000).

European Committee for Standardization. EN 772-1: Methods of test for masonry units. Part 1: Determination of compressive strength (2002).

European Committee for Standardization. EN 772-13: Methods of test for masonry units. Part 13: Determination of net and gross density of masonry units (except for natural stone) (2002).

European Committee for Standardization. Eurocode 6: Design of masonry structures, Part 1-1: Common rules for reinforced and unreinforced masonry structures (2003).

European Committee for Standardization. EN 1052-3: Methods of test for masonry. Determination of initial shear strength (2005).

European Committee for Standardization. EN 998-2: Specification for mortar for masonry. Masonry mortar. (2010).

Garcia, P. (2000). Contribution to the study of the compressive strength of masonry walls composed by ceramic bricks. (MSc thesis). Engineering School of São Carlos, University of São Paulo, Brazil.

Gouveia, J. P., \& Lourenço, P. B. (2007). Masonry shear walls subjected to cyclic loading: influence of confinement and horizontal reinforcement. In Proceedings of the Tenth North American Masonry Conference, The Masonry Society. USA.

Haach, V. (2009). Development of a design method for reinforced masonry subjected to in-plane loading based on experimental and numerical analysis (PhD Thesis). School of Engineering, University of Minho, Portugal.

Hak, S., Morandi, P., Magenes, G., \& Sullivan, T. J. (2012). Damage control for clay masonry infills in the design of RC frame structures. Journal of Earthquake Engineering, 16(sup1), 1-35.

Hamid, A., \& Drysdale, R. G. (1979). Behavior of concrete brick masonry under axial compression. American Concrete Institute Journal, 76(6), 707-721.

Hendry, E. A. W. (2001). Masonry walls: materials and construction. Construction and Building Materials, 15(8), 323330. https://doi.org/10.1016/S0950-0618(01)00019-8

Kaushik, H. B., Rai, D. C., \& Jain, S. K. (2007). Stress-Strain Characteristics of Clay Brick Masonry under Uniaxial Compression. Journal of Materials in Civil Engineering. Retrieved from http://ascelibrary.org/doi/abs/10.1061/(ASCE)0899-1561(2007)19:9(728)

Marčiukaitis, G., \& Valivonis, J. (2000). Estimation of Shrinkage Deformations of Masonry by Determining Cracking of Internal Building Walls. Statyba, 6(1), 11-16. https://doi.org/10.1080/13921525.2000.10531558

Marques, I., Neto, V., Grilo, I., Vieira, M., \& Júlio, E. (2012). Recycling of residual sludge from aluminium anodizing and lacquering in clay bricks-Case study of Portuguese industries. In 4th International Conference on Engineering from Waste and Biomass Valorization, Porto.

Mohamad, G. (2007). Failure mechanism of blocks masonry subjected to compression (PhD Thesis). School of Engineering, University of Minho, Portugal.

Monteagudo, S., Casati, M., \& Gálvez, J. (2015). Influence of the bed joint thickness on the bearing capacity of the brick masonry under compression loading: an ultrasound assessment. Revista de La Construcción, 14(1), 9-15.

Neto, V. C. (2010). Effect of the aluminium oxide in red clay (MSc thesis). University of Coimbra, Coimbra, Portugal.

Pérez-Lombard, L., Ortiz, J., \& Pout, C. (2008). A review on buildings energy consumption information. Energy and Buildings, 40(3), 394-398.

Raut, S., Ralegaonkar, R., \& Mandavgane, S. (2013). Utilization of recycle paper mill residue and rice husk ash in production of light weight bricks. Arch. Civ. Mech. Eng., 13(2), 269-275.

Santos, P., Martins, C., \& Júlio, E. (2015). Enhancement of the thermal performance of perforated clay brick walls through the addition of industrial nano-crystalline aluminium sludge. Construction and Building Materials, 101, 227-238.

Tiago, P., \& Júlio, E. (2010). Case study: Damage of an RC building after a landslide-inspection, analysis and retrofitting. Engineering Structures, 32(7), 1814-1820. https://doi.org/10.1016/j.engstruct.2010.02.018

Tomaževič, M. (2008). Shear resistance of masonry walls and Eurocode 6: shear versus tensile strength of masonry. Materials and Structures, 42(7), 889-907. https://doi.org/10.1617/s11527-008-9430-6 